\title{
Pelatihan Strategi Pembelajaran Daring Bagi Guru-Guru di SDN 01 dan 05 Pluit
}

\author{
Clara Ika Sari Budhayanti ${ }^{1}$, Lorensius Noel Praba ${ }^{2}$ \\ 1,2Pendidikan Guru Sekolah Dasar, Fakultas Pendidikan dan Bahasa, \\ Universitas Katolik Indonesia Atma Jaya \\ *e-mail : clara.ika@atmajaya.ac.id¹, lorensiusnoel@gmail.com²
}

\begin{abstract}
Online learning is one of the policies taken by the government to reduce the spread of the Covid-19 virus. Although online learning has been carried out for more than a year, teachers still have difficulty managing online learning. Difficulties in the management of this learning also occur in teachers in SDN 01 and 05 Pluit. This training aims to help teachers at SDN 01 and 05 Pluit to understand and design online learning with various online learning strategies. The training results showed that although teachers do not fully understand online learning, teachers have been able to design online learning shown by asynchronous and synchronic activities. The online learning plan is still straightforward, from the selection of learning platforms limited to WhatsApp group and Zoom Meetings and the use of YouTube and Quizziz learning media. Therefore, SDN 01 and 05 Pluit should follow up this training with other relevant training, such as learning platforms that enable students to learn.
\end{abstract}

Keywords: Learning Strategies, Online Learning

\begin{abstract}
Abstrak
Pembelajaran daring merupakan salah satu kebijakan yang diambil pemerintah untuk mengurangi penyebaran virus Covid-19. Meskipun pembelajaran daring sudah dilaksanakan selama satu tahun lebih, guru masih kesulitan dalam pengelolaan pembelajaran daring. Kesulitan dalam pengelolaan pembelajaran ini juga terjadi pada guru-guru di SDN 01 dan 05 Pluit. Pelatihan ini bertujuan untuk membantu guru di SDN 01 dan 05 Pluit untuk memahami dan merancang pembelajaran daring dengan berbagai strategi pembelajaran daring. Hasil pelatihan menunjukkan bahwa meskipun guru belum memahami pembelajaran daring seutuhnya, guru sudah mampu merancang pembelajaran daring yang ditunjukkan dengan adanya kegiatan asinkronus dan sinkronus. Rancangan pembelajaran daring masih sangat sederhana terlihat dari pemilihan platform pembelajaran yang terbatas pada WhatsApp group dan Zoom Meetings, serta penggunaan media pembelajaran YouTube dan Quizziz. Oleh karena itu disarankan bagi SDN 01 dan 05 Pluit untuk menindaklanjuti pelatihan ini dengan pelatihan-pelatihan lain yang relevan seperti penggunaan platform pembelajaran yang mengaktifkan siswa belajar.
\end{abstract}

Kata Kunci : Strategi Pembelajaran, Pembelajaran Daring

\section{PENDAHULUAN}

Selama pandemi Covid-19, pemerintah menerapkan kebijakan Work From Home (WFH) dan Study From Home (SFH) yang memiliki tujuan untuk memutus rantai penyebaran pandemi Covid-19. Dampak kebijakan tersebut, membawa perubahan yang besar terhadap pola aktivitas atau kegiatan di masyarakat termasuk juga di bidang pendidikan. Proses kegiatan belajar mengajar yang sebelumnya dilakukan secara tatap muka atau luar jaringan (luring) menjadi pembelajaran secara online atau dalam jaringan (daring). Pandemi Covid-19 membuat semua institusi pendidikan mendadak menyelenggarakan pembelajaran jarak jauh, terutama secara daring. Pembelajaran jarak jauh secara daring adalah pembelajaran jarak jauh yang cara pengantaran bahan ajar dan interaksinya dilakukan dengan perantara teknologi internet (Direktorat Pembelajaran dan Kemahasiswaan, Ditjen Dikti, 2020). Merujuk pada Permendikbud No. 109/2013 dikatakan bahwa pembelajaran daring merupakan proses belajar mengajar yang dilaksanakan secara jarak jauh melalui penggunaan berbagai media komunikasi. Pembelajaran 
daring dapat dilakukan dengan menggunakan teknologi multimedia, kelas virtual, CD ROM, streaming video, pesan suara, email dan telepon konferensi, teks online animasi, dan video streaming online (Thorme dalam Kuntarto, 2017).

Banyak kendala yang timbul dalam pelaksanaan pembelajaran daring, diantaranya kesulitan guru dalam mengelola pembelajaran dan masih terfokus dalam penuntasan kurikulum (Kemendikbud, 2020). Hal yang sama diungkapkan oleh Rigianti (2020) dalam penelitiannya yang menyimpulkan bahwa salah satu yang dialami guru selama pembelajaran daring adalah pengelolaan pembelajaran. Selain terkendala dalam pengelolaan pembelajaran, Rigianti juga menyebutkan bahwa guru terkendala dengan penggunaan aplikasi pembelajaran dan jaringan internet serta gadget yang digunakan baik dari sisi guru maupun siswa. Kendala yang sama juga dialami oleh guru-guru di SDN 01 Pluit. Berdasarkan jajak pendapat dengan guru SDN 01 Pluit diketahui bahwa selama masa pandemi Covid-19 ini, guru tidak dapat menerapkan sistem pembelajaran daring secara penuh. Pembelajaran biasanya dilakukan dengan menggunakan aplikasi WhatsApp group untuk memberikan materi, pekerjaan rumah, melakukan video call dengan siswa atau orang tua siswa, atau guru mengirimkan video pembelajaran kepada siswa. Pada dasarnya aplikasi WhatsApp cukup potensial untuk dimanfaatkan sebagai media tambahan pembelajaran. (Anwar \& Riadi, 2017) mendefinisikan WhatsApp sebagai aplikasi chatting yang bisa mengirim pesan teks, gambar, suara, lokasi dan juga video ke orang lain dengan menggunakan smartphone jenis apa pun. Penggunaan aplikasi WhatsApp cukup mudah, praktis, cepat, hemat data internet, serta memiliki beberapa fitur komunikasi, misalnya adanya menu grup, video call baik individu maupun kelompok, dan lain-lain.

Pada aplikasi WhatsApp, guru dapat mengirimkan materi pembelajaran ataupun latihan soal dalam bentuk video, foto, gambar ataupun rekaman suara. Hal ini sesuai dengan pendapat Jumiatmoko (2016) yang menyatakan bahwa aplikasi WhatsApp merupakan aplikasi berbasis internet yang memudahkan penggunanya dalam berkomunikasi dengan fitur-fitur yang tersedia. Namun pembelajaran daring dengan menggunakan aplikasi WhatsApp menurut guru-guru SDN 01 Pluit, kurang maksimal karena tidak ada interaksi langsung dengan siswa. Guru menggunakan aplikasi WhatsApp semata-mata hanya sebagai media untuk memberikan dan menerima materi dan tugas. Akibatnya pembelajaran daring kurang dapat dilaksanakan secara maksimal karena tidak ada interaksi langsung dengan siswa. Hal ini membuat siswa cenderung malas dan sulit konsentrasi dalam pembelajaran sehingga siswa cenderung kurang memahami materi pelajaran. Kurang efektifnya penggunaan aplikasi WhatsApp ini juga dikemukakan oleh Baalwi (2020) yang mengatakan bahwa salah satu kendala guru dalam melaksanakan pembelajaran daring adalah tidak maksimalnya penyampaian materi karena masih melalui WhatsApp.

Pembelajaran daring memang memerlukan strategi pembelajaran yang sedikit berbeda dibandingkan pembelajaran tatap muka. Kemp dalam Nurdyansyah \& Fahyuni, E. F. (2016) menjelaskan bahwa strategi pembelajaran merupakan kegiatan pembelajaran yang harus dikerjakan oleh guru dan siswa agar tujuan pembelajaran dapat dicapai secara efektif dan efisien. Sejalan dengan pendapat tersebut, Dick and Carrey dalam Nurdyansyah \& Fahyuni, E. F. (2016) menyebutkan bahwa strategi pembelajaran adalah suatu materi dan prosedur pembelajaran yang digunakan secara bersama-sama untuk menimbulkan hasil belajar pada siswa. Jadi strategi pembelajaran memuat perencanaan yang berisi tentang rangkaian kegiatan yang telah didesain atau dirancang untuk mencapai tujuan pembelajaran tertentu. Giyarsi (2020) menyatakan bahwa pemilihan strategi pembelajaran oleh guru perlu memperhatikan karakteristik dan kondisi siswa sesuai dengan materi yang terkait, serta sangat diperlukan adanya strategi pembelajaran yang disusun secara sistematis dan semenarik mungkin sehingga dapat mencapai kompetensi yang diharapkan. 
Salah satu strategi dalam pembelajaran daring adalah penggunaan aplikasi atau media pembelajaran tertentu yang merupakan bentuk inovasi dari pendidikan. Penggunaan aplikasi atau media pembelajaran terutama yang berbasis digital menjawab kesulitan dan tantangan terhadap ketersediaan sumber belajar yang bervariasi. Hasil penelitian yang dilakukan Fuadi, T. M., dkk (2020) menunjukkan bahwa saat ini ada sembilan jenis aplikasi pembelajaran yang sering digunakan yaitu Zoom, Google Classroom, WhatsApp group, Google Meet, Skype, Webex, Email, Edmodo dan CamStudio. Namun tidak semua guru mampu menggunakan aplikasi-aplikasi pembelajaran tersebut. Guru perlu diberikan pelatihan dalam penggunaannya. Seperti kegiatan pengabdian kepada masyarakat yang dilakukan oleh (Awal et al., 2019) melalui pelatihan penggunaan aplikasi pembelajaran pada alat TIK modern, yaitu Edmodo.

Keberhasilan proses pembelajaran daring juga dilihat dari karakteristik siswa dan guru yang mendampingi selama pembelajaran. Tidak semua siswa yang mengikuti pembelajaran daring dapat berhasil karena bisa saja dipengaruhi oleh beberapa faktor, seperti karakteristik siswa, keadaaan atau kondisi dari faktor lingkungan, dan penggunaan akses internet. Banyak penelitian yang menunjukkan bahwa ketidakberhasilan pembelajaran daring ini dipengaruhi oleh kondisi siswa terkait dengan penggunaan gawai dan akses internet (Baalwi, 2020; Rigianti, 2020; Tambunan, N., 2021). Oleh karena itu baik kajian maupun pelatihan pembelajaran daring dengan menggunakan berbagai macam strategi pembelajaran, seperti pemanfaatan teknologi yang mendukung proses kegiatan pembelajaran merupakan kebutuhan bagi pengabdi dan guru sebagai upaya memenuhi tuntutan perkembangan teknologi sehingga mampu beradaptasi dengan perubahan-perubahan yang terjadi dalam dunia pendidikan. Subyek utama Pendidikan yaitu guru harus berani untuk mengimplementasikan dan mencoba berbagai aplikasi pembelajaran dengan berbagai platform yang tersedia baik dengan cara belajar sendiri, mengikuti pelatihan, atau webinar yang relevan. Pemilihan aplikasi pembelajaran dapat disesuaikan dengan kemampuan masing-masing guru dan fasilitas sekolah. Guru juga harus meningkatkan komunikasi yang intensif kepada siswa melalui strategi pembelajaran daring yang tepat dan sesuai kebutuhan siswa dengan berkoordinasi bersama orang tua siswa agar interaksi komunikasi dapat berjalan dengan efektif. Kegiatan pelatihan strategi pembelajaran dari ini merupakan salah satu kontribusi Unika Atma Jaya untuk membantu guru-guru khususnya di SDN 01 dan 05 Pluit untuk mengembangkan kompetensi pedagogiknya dalam merancang strategi pembelajaran daring, bukan hanya terkait dengan aplikasi pembelajaran berbasis digital yang digunakan namun juga penggunaan metode pembelajaran yang bervariasi sehingga memberikan banyak pengalaman belajar kepada siswa.

\section{METODE}

Pelatihan strategi pembelajaran daring ini diberikan kepada guru-guru di SDN 01 dan 05 Pluit yang berjumlah 27 guru dengan distribusi guru sebagai berikut.

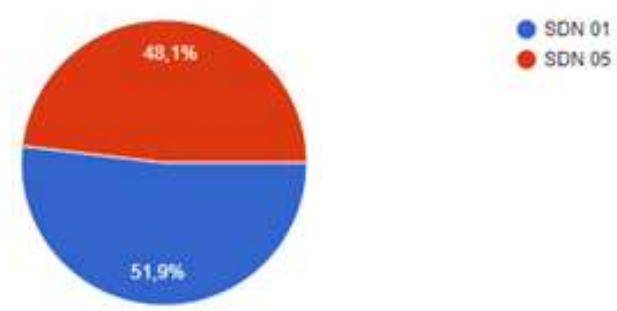

Gambar 1. Distribusi Frekuensi Guru SDN 01 dan 05 Pluit

Pelatihan dilakukan melalui metode ceramah dan workshop. Metode ceramah digunakan untuk memaparkan materi strategi pembelajaran daring yang dilakukan dengan menggunakan 
media Zoom Meetings. Sedangkan metode workshop dilakukan untuk membantu guru dalam merancang strategi pembelajaran daring. Workshop dilakukan secara mandiri dengan pendampingan.

\section{HASIL DAN PEMBAHASAN}

Pelatihan strategi pembelajaran daring ditujukan bagi guru-guru di SDN 01 dan 05 Pluit sebanyak 27 guru pada 22 Juli 2021. Sebelum pelatihan, guru diminta untuk mengisi kuesioner melalui aplikasi Google Form yang memuat beberapa pertanyaan untuk menggali persepsi guru terhadap pembelajaran daring. Persepsi ini digali melalui 4 komponen yaitu terkait dengan perolehan informasi, pemahaman, penilaian, dan evaluasi. Pada aspek perolehan informasi, diketahui bahwa 96,3\% peserta telah memperoleh informasi mengenai pembelajaran daring. Guru-guru memperoleh informasi terkait dengan pembelajaran daring ini dari sekolah maupun dari luar sekolah. Informasi dari luar sekolah diperoleh dari berbagai kegiatan seperti seminar, webinar, atau pelatihan. Seminar dan pelatihan merupakan salah satu strategi yang paling diminati dan sedang menjadi trend bagi guru dalam era sertifikasi, karena dapat menjadi sarana untuk mendapatkan angka kredit, sekaligus mendapatkan informasi-informasi baru (Notanubun Z., 2017). Selain itu guru-guru juga aktif mencari informasi dari YouTube atau website Kemendikbud yang menjelaskan pelaksanaan pembelajaran daring di masa pandemi Covid-19. Selanjutnya pada komponen pemahaman, 22,2\% guru menyatakan sudah sangat memahami pembelajaran daring dan sisanya masih belum memahami pembelajaran daring dengan baik. Data ini didukung dengan jawaban guru pada pertanyaan selanjutnya, dimana kebanyakan guru menyatakan bahwa faktor yang dapat mendukung pelaksanaan pembelajaran daring adalah fasilitas internet dan peralatan yang memadai.
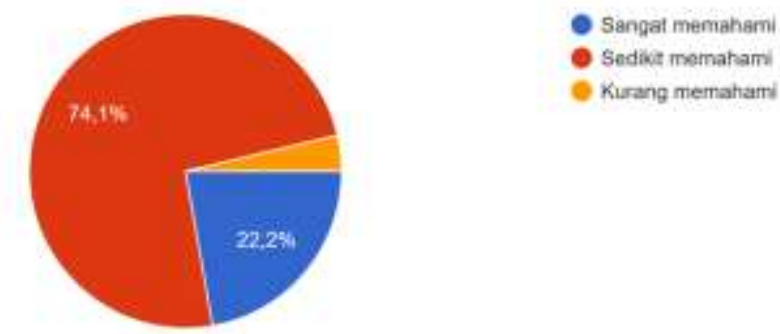

Gambar 2. Distribusi Frekuensi Persepsi Guru terhadap Pemahaman Pembelajaran Daring

Data ini sesuai dengan hasil penelitian yang dilakukan oleh Buanasari D. M. (2020) yang menyatakan bahwa salah satu pendukung terlaksananya pembelajaran daring di SD Negeri 12 Purwodadi adalah fasilitas kuota internet dari sekolah dan jaringan internet yang cukup baik. Selanjutnya dari hasil kuesioner, hanya ada beberapa guru yang menyebutkan faktor pendukung selain fasilitas yaitu terkait dengan motivasi siswa, kerja sama dengan orang tua, lingkungan sekolah dan rumah, serta kemampuan guru dan siswa dalam menggunakan dan memanfaatkan media pembelajaran berbasis internet. Hal ini sesuai dengan hasil penelitian yang dilakukan oleh Pradnyaswari N.P.D (2021) yang menyatakan bahwa faktor pendukung guru dalam pembelajaran daring adalah sarana prasarana yang memadai, kesiapan guru dalam merencanakan proses pembelajaran daring, kemahiran guru dalam penggunaan teknologi serta terjalinnya komunikasi antara guru dan orang tua. Kuesioner juga mengukur penilaian guru-guru terhadap pembelajaran daring. Sebanyak $48,1 \%$ guru menyatakan bahwa pembelajaran daring dapat meningkatkan kompetensi siswa, 37\% ragu-ragu dan 14,8\% menyatakan tidak. Selain itu sebanyak $51,9 \%$ guru ragu-ragu terhadap keefektifan proses pembelajaran daring yang telah dilakukan. Sementara sebanyak $37 \%$ guru menyatakan efektif dan $11,1 \%$ menyatakan tidak efektif. 

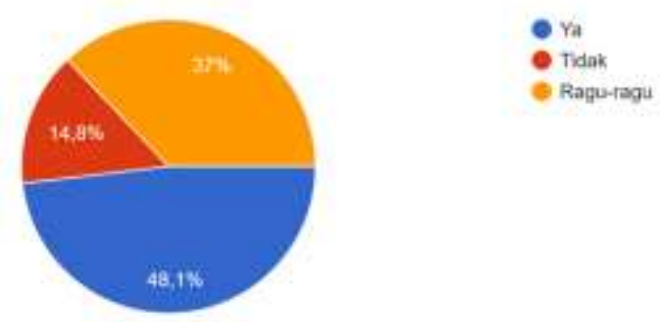

Gambar 3. Distribusi Frekuensi Persepsi Guru terhadap Keefektifan Pembelajaran Daring

Setelah pengisian kuesioner, guru menyimak pemaparan materi tentang strategi pembelajaran daring. Materi yang dipaparkan terdiri dari pengertian, karakteristik, manfaat dan kecenderungan serta keefektifan pembelajaran daring. Di akhir paparan materi, guru-guru diberikan tes untuk mengevaluasi pemahaman guru terkait materi yang diberikan. Secara umum, guru sudah masih belum memahami pembelajaran daring dengan baik. Hal ini ditunjukkan dengan rata-rata skor yang diperoleh sebesar 52,2\% yang berada dalam kategori sedang. Berdasarkan pengamatan, pemahaman yang belum baik dikarenakan pada saat pemaparan materi, guru tidak dapat fokus menyimak karena pada saat pelatihan sedang melaksanakan tugastugas atau kegiatan yang lain. Apabila dilihat dari setiap komponen pertanyaan, guru belum dapat dengan tepat menyebutkan manfaat dan kecenderungan pembelajaran daring. Sementara untuk pertanyaan yang terkait dengan pengertian, karakteristik dan keefektifan pembelajaran daring, kebanyakan guru dapat menjawabnya.

Pengertian pembelajaran daring dikutip dari Permendikbud No. 109 (2013) yang mendefinisikan pembelajaran daring sebagai proses belajar mengajar yang dilakukan secara jarak jauh melalui penggunaan berbagai media komunikasi. Pengertian pembelajaran daring juga dikutip dari Thorme dalam Kuntarto (2017) yang menyatakan bahwa pembelajaran daring adalah pembelajaran yang menggunakan teknologi multimedia, kelas virtual, CD ROM, streaming video, pesan suara, email dan telepon konferensi, teks online animasi, dan video streaming online. Pada pertanyaan terkait pengertian pembelajaran daring ini, sebanyak 20 guru dari 23 (87\%) menjawab pertanyaan dengan benar. Adapun pertanyaan yang diberikan meminta guru memilih pernyataan-pernyataan yang tidak benar terkait dengan pembelajaran daring.

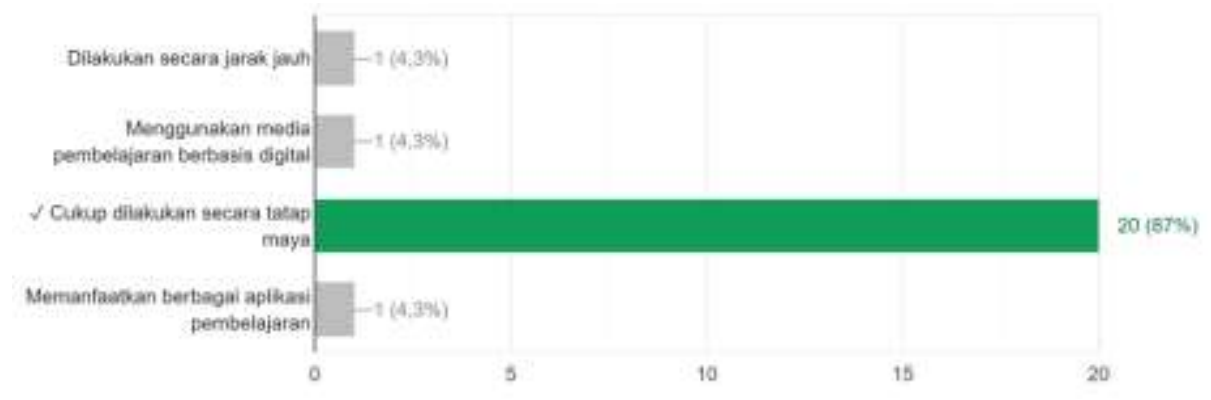

Gambar 4. Distribusi Frekuensi Jawaban Guru mengenai Pemahaman Pembelajaran Daring

Dari data tersebut menunjukkan bahwa guru sangat memahami bahwa pembelajaran daring tidak cukup hanya melalui kegiatan tatap maya menggunakan aplikasi Google Meet atau Zoom Meetings, namun juga harus menggunakan pembelajaran berbasis digital serta menggunakan berbagai aplikasi atau platform pembelajaran berbasis internet. Penggunaan berbagai media dan aplikasi digital berbasis internet akan mempengaruhi keefektifan pelaksanaan pembelajaran daring. Terkait dengan keefektifan pelaksanaan pembelajaran daring 
yang telah dilakukan, 86,2\% guru mengungkapkan bahwa pembelajaran tidak dapat berjalan efektif saja apabila pembelajaran dilakukan hanya dengan penugasan-penugasan saja. Adapun pertanyaan yang diberikan menuntut guru memilih pernyataan-pernyataan yang merupakan indikator pembelajaran daring berjalan dengan efektif.

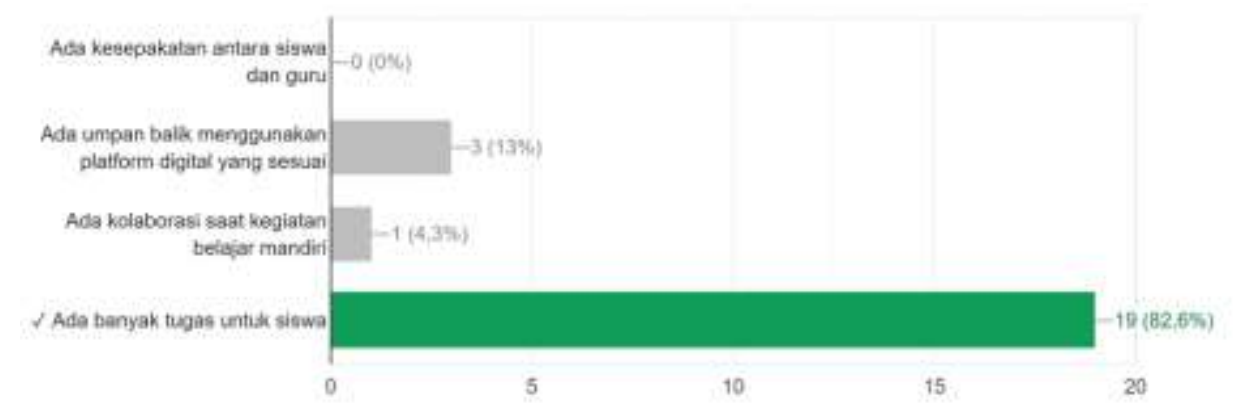

Gambar 5. Distribusi Frekuensi Jawaban Guru mengenai Keefektifan Pembelajaran Daring

Pembelajaran daring bukan hanya pembelajaran yang memindahkan materi melalui media internet dan memberikan tugas dan soal-soal yang dikirimkan melalui aplikasi sosial media. Proses pembelajaran daring merupakan hal yang kompleks karena melibatkan aspek pedagogis, psikologis, dan didaktis secara bersamaan (Mulyasa, 2013). Ada banyak faktor yang mempengaruhi keefektifan pembelajaran daring. Salah satunya diungkapkan oleh Fauzi (2020) yang menyatakan bahwa proses pembelajaran daring tergantung pada kesepakatan guru dengan siswa dalam kontrak pembelajaran selama masa pandemi berlangsung agar tercapai tujuan pembelajaran yang efektif dan efisien. Hal ini ditegaskan dalam Surat Edaran Nomor 15 Tahun 2020 tentang Pedoman Penyelenggaraan Belajar dari Rumah dalam Masa Darurat Penyebaran Corona Virus Disease (Covid-19) yang dikeluarkan oleh kemendikbud yang menyatakan bahwa waktu pembelajaran dan pengumpulan hasil belajar dilakukan sesuai kesepakatan antara siswa, orang tua, dan guru serta satuan pendidikan. Selain kesepakatan, pembelajaran daring harus memberikan variasi aktivitas dan tugas pembelajaran belajar dari rumah antarsiswa, sesuai minat dan kondisi masing-masing, termasuk mempertimbangkan kesenjangan akses/fasilitas belajar dari rumah. Pembelajaran daring juga harus memberikan umpan balik terhadap bukti atau produk aktivitas belajar dari rumah yang bersifat kualitatif dan berguna bagi guru, tanpa diharuskan memberi skor/nilai kualitatif (Kemendikbud, 2020). Hal ini sejalan dengan pendapat Kartika A. R. (2018) yang menyatakan bahwa pembelajaran daring dapat menjadi metode pembelajaran yang efektif, jika dilakukan dengan menggabungkan kolaborasi kegiatan dengan belajar mandiri, personalisasi pembelajaran berdasarkan kebutuhan siswa, penggunaan simulasi dan permainan serta adanya kegiatan berlatih dengan adanya umpan balik terkait.

Pembelajaran daring dalam arti luas bisa mencakup pembelajaran yang dilakukan di media elektronik (internet) baik secara formal maupun informal. Pembelajaran daring secara formal misalnya adalah pembelajaran dengan kurikulum, silabus, mata pelajaran dan tes yang telah diatur dan disusun berdasarkan jadwal yang telah disepakati pihak-pihak terkait. Sedangkan pembelajaran daring informal dilakukan dengan interaksi yang lebih sederhana, misalnya melalui sarana mailing list, e-newsletter atau website pribadi (Imania, K. A. \& Bariah, K. S., 2019). Hal ini dipahami dengan lebih sederhana oleh guru-guru peserta pelatihan sebanyak $47,8 \%$ dimana formal dan informal dalam pembelajaran daring dipahami sebagai bentuk-bentuk komunikasi belajar antara guru dan siswa. Sementara masih ada 5 guru atau sebanyak 21,7\% guru yang memandang pembelajaran daring tetap sebagai proses pembelajaran yang dilakukan secara formal. Selain itu ada juga guru sebanyak 4 guru $(17,4 \%)$ yang beranggapan bahwa yang disebut pembelajaran adalah proses belajar mengajar yang dilakukan secara langsung. Padahal dalam pembelajaran daring, pembelajaran dapat dilakukan secara langsung maupun tidak langsung. Seperti yang diungkapkan oleh Tung dalam Mustofa, Chodzirin, \& Sayekti (2019) yang 
menyebutkan bahwa komunikasi dalam pembelajaran daring dapat dilakukan secara langsung menggunakan video conference atau secara tidak langsung menggunakan chats rooms, atau discussion forums.

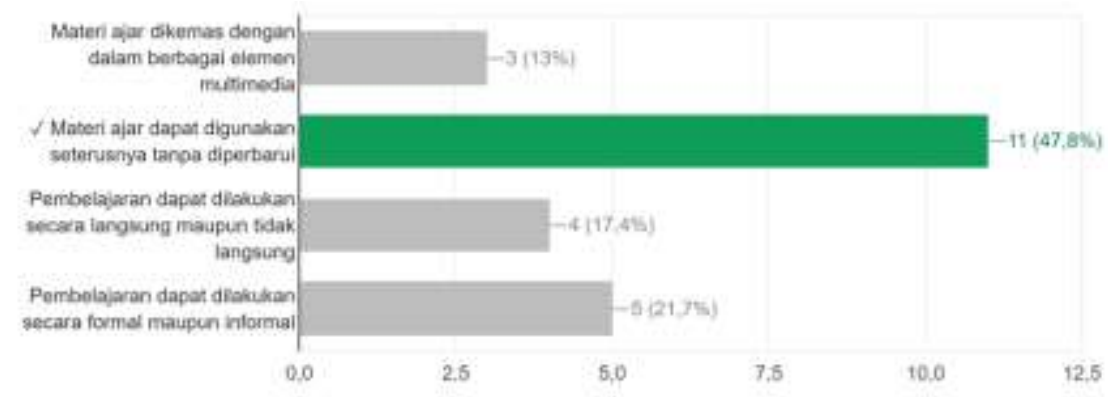

Gambar 6. Distribusi Frekuensi Jawaban Guru mengenai Karakteristik Pembelajaran Daring

Pada pembelajaran daring, guru memang diharapkan mampu menyampaikan materi pembelajaran yang cukup menarik. Penyampaian materi harus dikemas sedemikian rupa sehingga memfasilitasi kebutuhan siswa dalam pembelajaran aktif. Salah satu kelebihan pembelajaran daring adalah kemudahan dalam penyimpanan dan pembaharuan materi pembelajaran yang dapat disesuaikan dengan kebutuhan siswa. Pemahaman yang benar terkait pengemasan materi ini belum sepenuhnya dipahami dengan baik oleh peserta pelatihan. Hal ini terbukti dari 23 guru sebanyak 39,1\% guru menyatakan bahwa materi pembelajaran tidak mudah disimpan secara online dan sebanyak 47,8\% guru menyatakan bahwa materi pembelajaran sulit atau tidak mudah untuk diperbaharui. Selain itu masih ada sebanyak 13\% guru yang menganggap bahwa materi tidak dapat dikemas dengan berbagai elemen multimedia sesuai dengan karakteristik dan kebutuhan siswa.

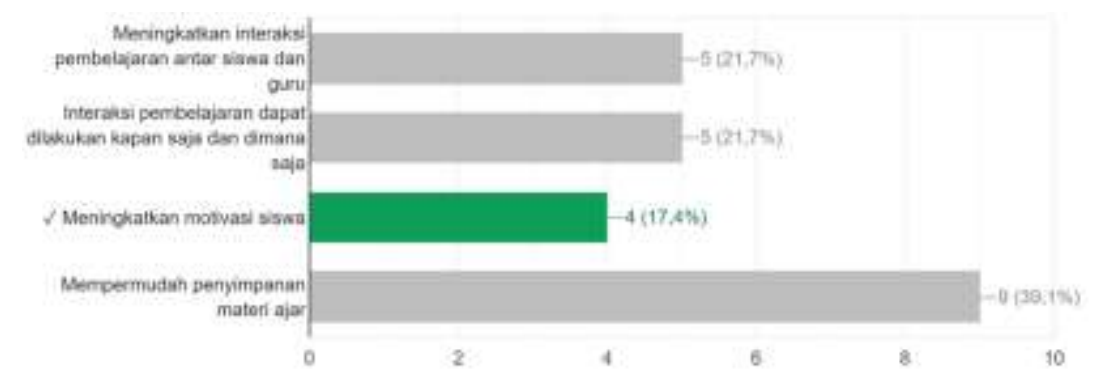

Gambar 7. Distribusi Frekuensi Jawaban Guru mengenai Manfaat Pembelajaran Daring

Data tersebut menunjukkan bahwa tidak mudah memberikan pemahaman yang benar terkait pengemasan materi pembelajaran daring kepada para guru. Selama pelaksanaan pembelajaran daring yang telah dilakukan, sebanyak $92 \%$ guru mengandalkan aplikasi WhatsApp untuk menyampaikan materi dan tugas. Pemberian materi dan tugas merupakan salah satu karakteristik pelatihan, sifat pendidikan sendiri kurang tersampaikan kepada siswa seperti pengembangan kompetensi sosial siswa. Temuan ini sesuai dengan pendapat Hadisi dan Muna (2015) terkait dengan kendala pembelajaran daring proses belajar dan mengajar yang cenderung ke arah pelatihan dari pada pendidikan.

Penggunaan aplikasi WhatsApp sebagai satu-satunya aplikasi yang digunakan menunjukkan bahwa tidak banyak guru yang mengintegrasikan elemen multimedia lain dalam proses pembelajaran daring. Proses pembelajaran yang dilakukan dengan cara demikian tidak akan meningkatkan interaksi pembelajaran terutama interaksi siswa dengan siswa atau siswa dengan media pembelajaran. Tidak heran jika hasil kuesioner di akhir pelatihan menunjukkan bahwa sebanyak 21,7\% guru menyatakan bahwa pembelajaran daring kurang dapat 
meningkatkan interaksi pembelajaran karena pembelajaran hanya dilakukan dengan metode penugasan. Kondisi ini memang menjadi kendala umum di sekolah-sekolah selama pembelajaran daring, seperti yang dikemukakan oleh Hadisi dan Muna (2015) bahwa interaksi antara guru dan siswa terutama interaksi antar siswa itu sendiri sangat kurang sehingga mengakibatkan keterlambatan terbentuknya nilai-nilai dalam proses belajar-mengajar. Sebanyak $21,7 \%$ guru peserta pelatihan masih memiliki persepsi bahwa proses pembelajaran daring hanya terjadi saat penugasan atau saat Zoom Meetings saja. Guru juga berpendapat bahwa pembelajaran daring tidak dapat dilakukan kapan saja dan dimana saja. Hal ini bertentangan dengan pendapat dari Mustakim (2020) yang mengungkapkan bahwa kelebihan pembelajaran berbasis daring bagi guru antara lain, penyampaian materi pembelajaran tanpa dibatasi ruang dan waktu. Sementara dilihat dari sisi siswa, siswa dapat dengan mudah mengakses materi pembelajaran dimana pun dan kapan pun tanpa terbatas baik dari segi tempat maupun waktu.

Pelatihan strategi pembelajaran yang diberikan kepada guru-guru di SDN 01 dan 05 Pluit memberikan kesadaran bahwa proses pembelajaran daring yang sudah dilakukan belum secara maksimal membantu siswa dalam belajar. Diketahui sebanyak $83 \%$ guru mengakui bahwa proses belajar mengajar yang dilakukan secara daring pada masa pandemi tidak banyak membuahkan hasil. Guru juga mengungkapkan bahwa siswa jadi malas belajar, sulit konsentrasi, kurang memahami pelajaran, dan kurang semangat (terdemotivasi) dalam belajar. Pada dasarnya guru memahami bahwa pembelajaran daring yang dilakukan cenderung kurang dapat memotivasi siswa $(26,1 \%)$. Motivasi yang kurang dalam belajar akan berdampak pada hasil belajar siswa. Kondisi ini secara umum memang menjadi kendala dalam pelaksanaan pembelajaran daring, seperti yang diungkapkan Hadisi dan Muna (2015) yang menyatakan bahwa siswa yang tidak mempunyai motivasi belajar yang tinggi cenderung gagal dalam pembelajaran daring. Selanjutnya untuk melihat peningkatan kemampuan guru dalam menyusun strategi pembelajaran daring, guru diberi tugas untuk menyusun RPP.

Pada saat penyusunan, guru dapat berkonsultasi dengan pengabdi baik secara langsung maupun tidak langsung melalui grup WhatsApp atau Zoom Meetings yang dilaksanakan pada 29 Juli 2021 Pada saat pendampingan penyelesaian tugas ini, tidak banyak guru yang bersedia mengkonsultasikan RPP yang disusunnya. Pada saat Zoom Meetings pun tidak banyak guru yang hadir. Sementara guru yang hadir lebih banyak menanyakan hal-hal yang terkait dengan penggunaan media berbasis digital seperti Quizizz, Kahoot, dan lainnya. Total guru yang menyelesaikan tugas sebanyak hanya sebanyak 8 guru $(34,8 \%)$. Dari kedelapan guru yang menyelesaikan tugas hanya 3 guru yang menggunakan format baku RPP, sementara 5 yang lainnya berupa teks prosedur kegiatan belajar.
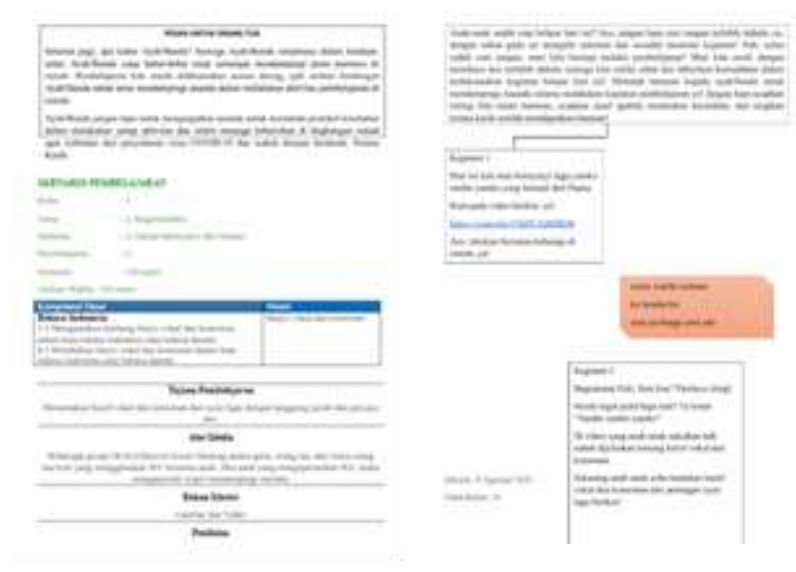

Gambar 8. Rancangan Pembelajaran dengan Teks Prosedur Kegiatan Pembelajaran 
Pada perancangan yang dilakukan, strategi pembelajaran yang dipilih oleh guru, antara lain

1. Pemilihan aplikasi pembelajaran yang dipilih masih terbatas pada platform WhatsApp group dan Zoom Meetings.

2. Beberapa rancangan sudah menunjukkan kegiatan asinkronus dan sinkronus.

3. Media pembelajaran yang digunakan masih terbatas pada video YouTube dan Quizizz.

4. Aktivitas belajar masih terbatas pada penugasan baik secara tertulis maupun dengan media Quizizz.

Pemilihan strategi ini memang masih sangat sederhana, namun apabila dibandingkan dengan kemampuan awal guru dalam memilih strategi pembelajaran terlihat adanya peningkatan terutama dalam pemilihan media Quizizz. Quizizz merupakan sebuah web tool yang berupa permainan kuis online yang dapat digunakan sebagai penilaian formatif dalam pembelajaran ((Basuki \& Hidayati, 2019); Chaiyo \& Nokham, 2017). Media Quizizz ini merupakan media yang cukup sederhana sehingga guru-guru mudah dalam pengaplikasiannya di pembelajaran daring. Penggunaan media Quizizz ini juga cukup efektif dalam meningkatkan aktivitas belajar siswa seperti penelitian yang dilakukan Salsabila, U. H., dkk (2020) yang menyimpulkan bahwa aplikasi Quizizz sebagai media pembelajaran, dapat membantu siswa memahami soal secara mandiri, siswa aktif, baik bertanya mengenai materi maupun mengevaluasi dan mencatat materi, siswa menjadi lebih teliti dalam mengerjakan soal dan manajemen waktu.

\section{KESIMPULAN}

Berdasarkan hasil pelatihan yang diberikan, dapat disimpulkan bahwa guru-guru SDN 01 dan 05 Pluit belum secara utuh memahami pemilihan strategi pembelajaran daring yang tepat dan memenuhi kebutuhan siswa. Pemilihan strategi pembelajaran masih terbatas pada penggunaan media pembelajaran. Aktivitas belajar siswa yang dirancang belum secara utuh mengembangkan kompetensi siswa. Oleh karena itu, disarankan bagi SDN 01 dan 05 Pluit untuk menindaklanjuti pelatihan ini dengan pelatihan-pelatihan lain yang relevan seperti penggunaan platform pembelajaran yang mengaktifkan siswa belajar.

\section{UCAPAN TERIMA KASIH}

Pengabdi mengucapkan terima kasih kepada Lembaga Penelitian dan Pengabdian Masyarakat (LPPM) Universitas Katolik Indonesia Atma Jaya yang telah memberi kesempatan dan dukungan kepada pengabdi untuk melakukan kegiatan pengabdian kepada masyarakat ini. Ucapan terima kasih juga kami sampaikan kepada kepala sekolah dan guru-guru di SDN 01 dan 05 Pluit atas kerja sama yang baik dalam pelaksanaan kegiatan ini.

\section{DAFTAR PUSTAKA}

Anwar, N., \& Riadi, I. (2017). Analisis investigasi forensik whatsapp messenger smartphone Terhadap whatsapp berbasis web. 3(1), 1-10. https://doi.org/10.26555/jiteki.v3i1.6643

Awal, R., Wahyuni, S., \& Martala, S. (2019). Pelatihan penggunaan aplikasi edmodo bagi guru SMP dan SMA SMART Indonesia Pekanbaru. 3(1), 69-75. https://doi.org/10.31849/dinamisia.v3i1.2218

Basuki, Y., \& Hidayati, Y. N. (2019). Kahoot ! or Quizizz : The students ' perspectives. Proceedings of the 3rd English Language and Literature International Conference, ELLiC. https://doi.org/10.4108/eai.27-4-2019.2285331 
Baalwi, M. A. (2020). Kendala guru dalam proses pembelajaran online selama masa pandemi ditinjau dari kemampuan information technology (IT) guru. Lintang Songo: Jurnal Pendidikan, $3(2), 38-45$

Y. Chaiyo and R. Nokham, "The effect of Kahoot, Quizizz and Google Forms on the student's perception in the classrooms response system," 2017 International Conference on Digital Arts, Media, and Technology (ICDAMT), 2017, pp. 178-182, doi: 10.1109/ICDAMT.2017.7904957.

Buanasari, D. M. (2020). Analisis pelaksanaan pembelajaran daring bagi guru kelas rendah pada pandemi Covid-19 di SD Negeri 12 Purwodadi. Skripsi tidak dipublikasikan. Surakarta: Universitas Muhammadiyah Surakarta

Fauzi. (2020). Strategi pembelajaran masa pandemi Covid-19 STIT Al-Ibrohimy Bangkalan. Jurnal Al-Ibrah, $\quad 5(2)$,

120-145, http://ejournal.stital.ac.id/index.php/alibrah/article/view/104

Fuadi, T. M., dkk. (2020). Covid-19: Penerapan pembelajaran daring di Perguruan Tinggi. Jurnal

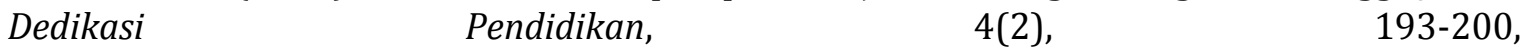
http://jurnal.abulyatama.ac.id/index.php/dedikasi/article/view/1022

Giyarsi. (2020). Strategi alternatif dalam pembelajaran daring Pendidikan Agama Islam pada masa pandemi Covid 19. GHAITSA: Islamic Education Journal, 1(3), 224-244, https://siducat.org/index.php/ghaitsa/article/view/108

Hadisi dan Muna. (2015). Pengelolaan teknologi informasi dalam menciptakan model inovasi pembelajaran (e-learning). Al-Ta'dib Jurnal Kajian Ilmu Kependidikan, 8(1), 117-140, DOI: 10.31332/atdb.v8i1.396

Imania, K. A. \& Bariah, K. S. 2019. Rancangan pengembangan instrumen penilaian pembelajaran berbasis daring. Jurnal PETIK, 5(1), 31-47, DOI: 10.31980/jpetik.v5i1.445

Jumiatmoko. (2016). WhatsApp messenger dalam tinjauan manfaat dan adab. Wahana Akademika: Jurnal Studi Islam dan Sosial, 3(1), 51-66, DOI: 10.21580/wa.v3i1.872

Kartika, A. R. (2018). Model pembelajaran daring matakuliah kajian PAUD di Jurusan PG PAUD Fakultas Ilmu Pendidikan Universitas Negeri Surabaya. Journal of early childhood care \& education, 1(1), 26-31

Kemendikbud. (2013). Permendikbud No. 109 tentang penyelenggaraan pendidikan jarak jauh pada Pendidikan Tinggi. Jakarta: Kementerian Pendidikan dan Kebudayaan.

Kemendikbud. (2020). Penyesuaian keputusan bersama empat menteri tentang panduan pembelajaran di masa pandemi COVID-19. Diakses pada Agustus, 14, 2021 dari https://www.kemdikbud.go.id/main/blog/2020/08/penyesuaian-keputusan-bersamaempat-menteri-tentang-panduan-pembelajaran-di-masa-pandemi-covid19

Kemendikbud. (2020). Surat Edaran Nomor 15 Tahun 2020 tentang Pedoman Penyelenggaraan Belajar dari Rumah dalam Masa Darurat Penyebaran Corona Virus Disease (Covid-19). Diakses pada Agustus, $14, \quad 2021$ dari http://www.sman8bpp.sch.id/data_sekolah/SE_Sesjen_Nomor_Tahu.pdf

Kuntarto, E. (2017). Keefektifan model pembelajaran daring dalam perkuliahan Bahasa Indonesia di Perguruan Tinggi. Indonesian Language Education and Literature, 3(1), 99-110, DOI: 10.24235/ileal.v3i1.1820

Mulyasa. (2013). Pengembangan dan implementasi Kurikulum 2013. Bandung: PT Remaja Rosdakarya

Mustakim. (2020). Efektivitas pembelajaran daring menggunakan media online selama pandemi Covid-19 pada mata pelajaran Matematika. Al asma: Journal of Islamic Education, 2(1), 1-12, DOI: 10.24252/asma.v2i1.13646

Mustofa, Chodzirin, dan Sayekti. (2019). Formulasi model perkuliahan daring sebagai upaya menekan disparitas kualitas Perguruan Tinggi. Walisongo Journal of Information Technology, 1(2), 151-160, DOI : 10.21580/wjit.2019.1.2.4067

Notanubun Z. (2017). Pengembangan kompetensi dan profesionalisme guru. Prosiding Seminar Nasional HDPGSDI Wilayah IV Tahun 2017. ISBN: 978-602-51434-0-3 
Nurdyansyah \& Fahyuni, E. F. (2016). Inovasi model pembelajaran: sesuai kurikulum 2013. Sidoarjo: Nizamia Learning Center

Pradnyaswari N. P. D. (2021). Faktor pendukung dan penghambat pembelajaran daring di masa Covid-19 pada guru Sekolah Dasar. Thesis tidak dipublikasikan. Bali: Universitas Pendidikan Ganesha

Raharjo. (2013). Peningkatan kompetensi guru dalam penyusunan KTSP: Studi tentang Efektifitas Program SSQ di Madrasah di Kabupaten Pati. Skripsi tidak dipublikasikan. Semarang: IAIN Walisongo

Rigianti, H. A. (2020). Kendala pembelajaran daring guru sekolah dasar di Banjarnegara. Elementary School: Jurnal Pendidikan dan Pembelajaran Ke-SD-an, 7(20), 297-302, DOI: 10.31316/esjurnal.v7i2.768

Salsabila, U. H., dkk. (2020). Pemanfaatan aplikasi quizizz sebagai media pembelajaran di tengah pandemi pada siswa SMA. Jurnal Ilmiah Ilmu Terapan Universitas Jambi, 4(2), 163-172, DOI: 10.22437/jiituj.v4i2.11605

Tambunan, N. (2021). Penggunaan aplikasi whatsapp pada pembelajaran jarak jauh pada siswa kelas V. Jurnal Pionir LPPM Universitas Asahan, 7(2), 43-49, http://jurnal.una.ac.id/index.php/pionir/article/view/2173/1692 